\title{
Effect of the Different High Volume Fraction of SiC Particles on the Junction of Bismuthate Glass-SiC $\mathrm{p}_{\mathrm{p}} / \mathrm{Al}$ Composite
}

\author{
Bin Wang $\mathbb{D}^{1,2}$ Shengguan $Q \mathbf{u} \mathbb{D}^{1,2}$ and Xiaoqiang $\mathrm{Li}^{1,2}$ \\ ${ }^{1}$ Guangdong Key Laboratory for Processing and Forming of Advanced Metallic Materials, South China University of Technology, \\ Guangzhou 510640, China \\ ${ }^{2}$ National Engineering Research Center of Near-Net-Shape Forming for Metallic Materials, South China University of Technology, \\ Guangzhou 510640, China
}

Correspondence should be addressed to Bin Wang; mewangbin@mail.scut.edu.cn and Shengguan Qu; qusg@scut.edu.cn

Received 22 October 2017; Revised 24 December 2017; Accepted 17 January 2018; Published 20 February 2018

Academic Editor: Francesco Ruffino

Copyright (C) 2018 Bin Wang et al. This is an open access article distributed under the Creative Commons Attribution License, which permits unrestricted use, distribution, and reproduction in any medium, provided the original work is properly cited.

\begin{abstract}
The in-house developed bismuthate glass and the $\mathrm{SiC}_{\mathrm{p}} / \mathrm{Al}$ composites with different volume fractions of $\mathrm{SiC}$ particles (namely, 60 vol. $\%, 65$ vol. $\%, 70$ vol. $\%$, and 75 vol.\%) were jointed by vacuum hot-pressing process. The novel material can be used for the space mirror. The $\mathrm{SiCp}$ is an abbreviation for $\mathrm{SiC}$ particle. Firstly, the $\mathrm{SiC}_{\mathrm{p}} / \mathrm{Al}$ composites with different vol.\% of $\mathrm{SiC}$ particle were manufactured by using infiltration process. In order to obtain a stable bonding interface, the preoxide layers were fabricated on the surfaces of these composites for reacting with the bismuthate glass. The coefficient of thermal expansion (CTE) was carried out for characterizing the difference between the composites and bismuthate glass. The sealing quality of the composites and the bismuthate glass was quantified by using shear strength testing. The optical microstructures showed the particles were uniformly distributed in the $\mathrm{Al}$ matrix. The SEM image shows that a smooth oxidation layer was generated on the $\mathrm{SiC}_{\mathrm{p}} / \mathrm{Al}$ composite. The CTE testing result indicated that the higher the vol.\% of the particles in the composite, the lower the CTE value. The shear strength testing result disclosed that $\mathrm{SiC}_{\mathrm{p}} / \mathrm{Al}$ composite with relatively low $\mathrm{CTE}$ value was favorable to obtain a bonding interface with high strength.
\end{abstract}

\section{Introduction}

With the rapid development of aerospace optical systems, more and more aerospace researchers are paying their attention to the materials applied in large-scale space-based mirror [1]. As an important component for use in aerospace, the space-based mirrors have to satisfy the strict functional requirements with lightweight, sound dimensional stability, and good resistance to thermal shock. In addition, the usability of this mirror in the space environment mainly depends on the bond strength of the sealing quality between the glass and the substrate of the mirror. During the past decades, the most commonly used materials for space-based mirrors are beryllium [2], Zerodur [3], and ULE [4]. These glasses are usually installed to the metal frame (e.g., Invar or Kovar alloys) of the space mirror by using the special glues [5].

In order to decrease the cost and weight and increase the strength of this mirror and sealing reliability of the glass on the substrate of the mirror, $\mathrm{SiC}_{\mathrm{p}} / \mathrm{Al}$ composites have been deemed as the candidate $[6,7]$. As one of the most popular aluminum matrix composites (AMCs), $\mathrm{SiC}_{\mathrm{p}} / \mathrm{Al}$ with high $\mathrm{SiC}$ volume fraction possesses high polishability, high specific strength, low density, and low coefficient of thermal expansion (CTE). After preparing the oxidation film (which can be obtained by using natural oxidation, anodizing or plasma electrolytic oxidation processes) on $\mathrm{SiC}_{\mathrm{p}} / \mathrm{Al}$ composite, the sealing reliability of this mirror fabricated by the composites and glasses will be enhanced. In our previous study [8], a novel space mirror was developed by using the bismuthate glass sealed with the preoxidized $\mathrm{SiC}_{\mathrm{p}} / \mathrm{Al}$ composite (70 vol.\% $\mathrm{SiC}$ ). The shear strength of this composite-glass material reached $5.44 \mathrm{MPa}$ which was about $20 \%$ higher than that of the popular borosilicate glass-toKovar alloy joint material [9].

The chemical reaction and elements diffusion at the interface between bismuthate glass and preoxidized $\mathrm{SiC}_{\mathrm{p}} / \mathrm{Al}$ 
TABLE 1: Chemical composition of 6061-Al.

\begin{tabular}{lcccccccc}
\hline \multirow{2}{*}{ Specification } & \multicolumn{9}{c}{ Composition (wt\%) } & \multicolumn{2}{c}{$\mathrm{Al}$} \\
& $\mathrm{Cu}$ & $\mathrm{Mg}$ & $\mathrm{Fe}$ & $\mathrm{Si}$ & $\mathrm{Zn}$ & $\mathrm{Mn}$ & $\mathrm{Pb}$ \\
\hline Aluminium alloy & 0.26 & 1.10 & 0.23 & 0.96 & 0.24 & 0.17 & 0.09 \\
\hline
\end{tabular}

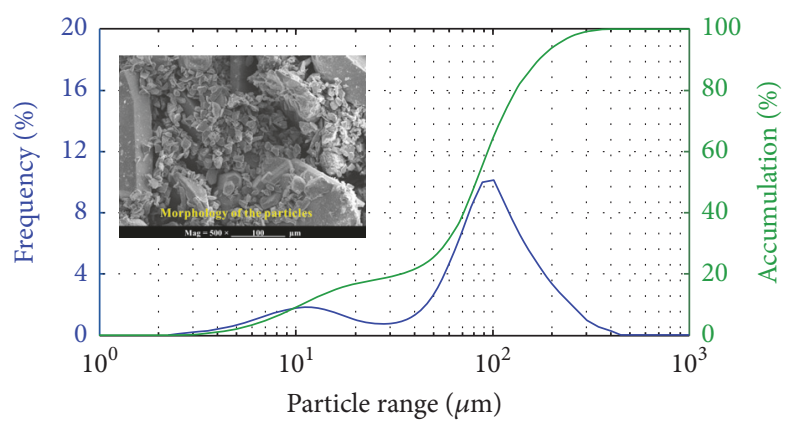

Figure 1: Morphologies and size distribution of $\mathrm{SiC}$ particles.

is favorable to the interfacial properties of glass-composite materials. Besides, the CTE value of $\mathrm{SiC}_{\mathrm{p}} / \mathrm{Al}$ composite also plays an important role in the bonding of glass-composite. Both the CTE value and the characteristic of the oxidation layer on $\mathrm{SiC}_{\mathrm{p}} / \mathrm{Al}$ composites are related to $\mathrm{SiC}$ volume fraction.

However, to the best of our knowledge, few works have been carried out on the association between the microstructure of $\mathrm{SiC}_{\mathrm{p}} / \mathrm{Al}$ composites and the bonding property of the bismuthate glass and $\mathrm{SiC}_{\mathrm{p}} / \mathrm{Al}$ composite material. In this study, the $\mathrm{SiC}_{\mathrm{p}} / \mathrm{Al}$ composites with different $\mathrm{SiC}$ volume fractions were prepared and preoxidized to joint with bismuthate glass. The CTE and mechanical properties of these composites were also tested for the assessment of their application prospect.

\section{Experiment}

2.1. Fabrication of $\mathrm{SiC}_{\mathrm{p}} / \mathrm{Al}$ Composites and Preoxidation of the Composites. Table 1 shows the composition of the commercial 6061 aluminum alloy used as the matrix of this composite. The green silicon carbide powders with three different average particle sizes, $2 \mu \mathrm{m}, 8 \mu \mathrm{m}$, and $128 \mu \mathrm{m}$, were blended by ball milling process and used in present study. Figure 1 shows the distributions of these $\mathrm{SiC}$ particles. It indicates the median diameters of these particles are about $2 \mu \mathrm{m}, 8 \mu \mathrm{m}$, and $128 \mu \mathrm{m}$. The colloidal silica (produced by Shanghai, Yanchen Industrial Co., Ltd, China) was carried out for the binder of $\mathrm{SiC}$ preform. The porous $\mathrm{SiC}$ particles preformed with the dimension of $\Phi 75 \mathrm{~mm} \times H 40 \mathrm{~mm}$ were sintered at $1600^{\circ} \mathrm{C}$ for $2 \mathrm{~h}$.

The $\mathrm{SiC}_{\mathrm{p}} / \mathrm{Al}$ composites with relatively high $\mathrm{SiC}$ volume fraction were fabricated via infiltration process. To begin with, the commercial 6061 alloy was melted in a graphite crucible at $750^{\circ} \mathrm{C}$. When the temperature of molten aluminum alloy was declined to about $700^{\circ} \mathrm{C}$ (tested by the thermocouple), it was removed to a steel container (preheated to 500) in the hydraulic pressure machine (Huzhou machine
TABLE 2: Chemical composition of bismuthate glass.

\begin{tabular}{lccc}
\hline $\mathrm{Bi}_{2} \mathrm{O}_{3}$ (wt.\%) & $\mathrm{B}_{2} \mathrm{O}_{3}$ (wt.\%) & $\mathrm{BaO}$ (wt.\%) & $\mathrm{Li}_{2} \mathrm{O}$ (wt.\%) \\
\hline 72.70 & 15.00 & 10.00 & 2.30 \\
\hline
\end{tabular}

tool plant, Co., Ltd, China). Thereafter, the Al melt was squeezed by the hydraulic machine and infiltrated into the $\mathrm{SiC}$ preform. The squeezing pressure was evenly changed from $8 \mathrm{MPa}$ to $90 \mathrm{MPa}$ during the solidification process of the composite (lasted for about $20 \mathrm{~min}$ ).

In our work, the $\mathrm{SiC}_{\mathrm{p}} / \mathrm{Al}$ composite oxidation film was prepared in the air atmosphere at $500^{\circ} \mathrm{C}$ with the holding time of $300 \mathrm{~min}$ (see details in Figure 2(a)). The oxidized surface of the $\mathrm{SiC}_{\mathrm{p}} / \mathrm{Al}$ composites was observed by SEM and given in Figure 2(b). It is clear that the thickness of this oxidized layer is about $2.01 \mu \mathrm{m}$. The upper part of the $\mathrm{Al}_{2} \mathrm{O}_{3}$ layer is $\mathrm{SiCp} / \mathrm{Al}$ composite.

2.2. Sealing of Bismuthate Glass and $\mathrm{SiC}_{\mathrm{p}} / \mathrm{Al}$ Composites. The in-house developed bismuthate glass for the application of aerospace was prepared by using the reagent grade $\mathrm{Bi}_{2} \mathrm{O}_{3}$ (72.7 wt.\%), $\mathrm{B}_{2} \mathrm{O}_{3}$ (15.0 wt.\%), $\mathrm{BaO}$ (10 wt.\%), and $\mathrm{Li}_{2} \mathrm{O}$ (2.3 wt.\%) as shown in Table 2 [8]. The bismuthate glass was melted in a graphite crucible. Thereafter, this bismuthate glass was vacuum hot press combined with the fabricated composites with four different $\mathrm{SiC}$ volume fractions $(60 \%$, $65 \%, 70 \%$, and $75 \%$, respectively). In order to precisely combine the glass and the composites, both of them were grounded and polished, respectively, before conducting the vacuum hot press composite process. The Germany BMT (Breitmeier Messtechnik GmbH) measurement was carried out for measuring the roughness of the polished surface of the composites and glass. The $\mathrm{SiC}_{\mathrm{p}} / \mathrm{Al}$ composites were polished to the roughness of $\mathrm{Ra} \approx 0.15 \mu \mathrm{m}$ in a JP06A single-axle grinding polisher (using a 3000 mesh diamond wheel), whilst the bismuthate glass was polished to the roughness of $\mathrm{Ra} \approx$ $0.025 \mu \mathrm{m}$ (using 500 mesh cerium oxide abrasive). Prior to 


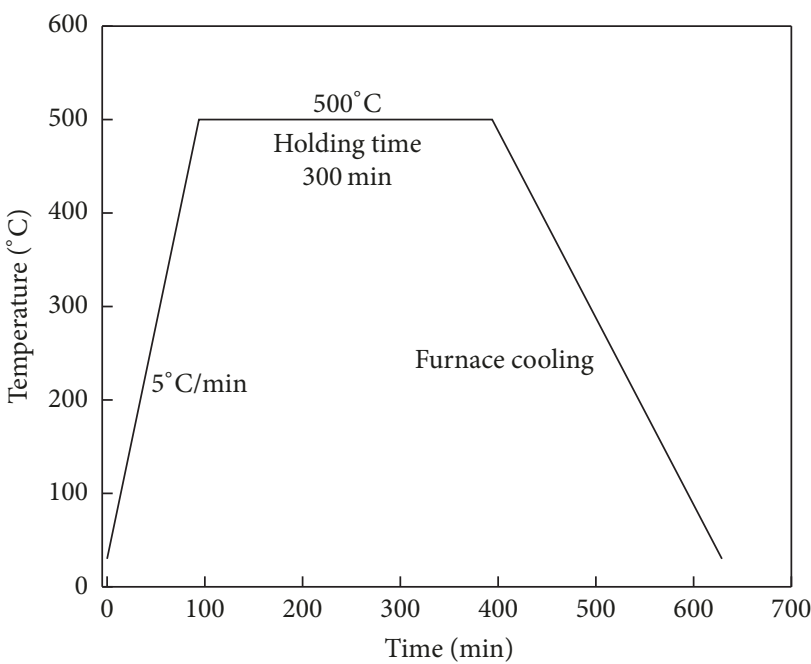

(a)

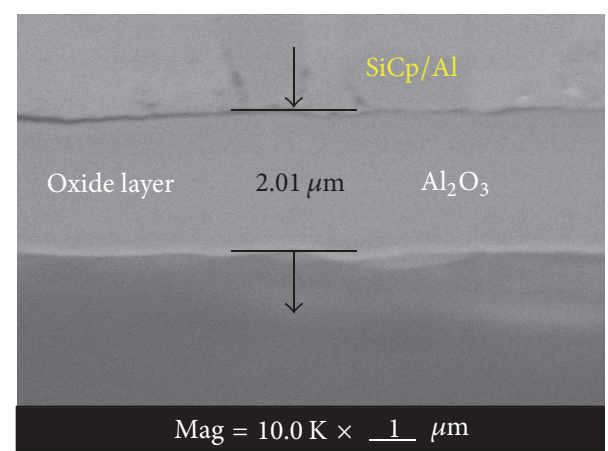

(b)

FIgURE 2: Preparation oxidation film of high volume fraction. (a) The process flow of preparing the oxidized layer on the composite and (b) the oxidized $\mathrm{Al}_{2} \mathrm{O}_{3}$ layer on the surface of the composites.

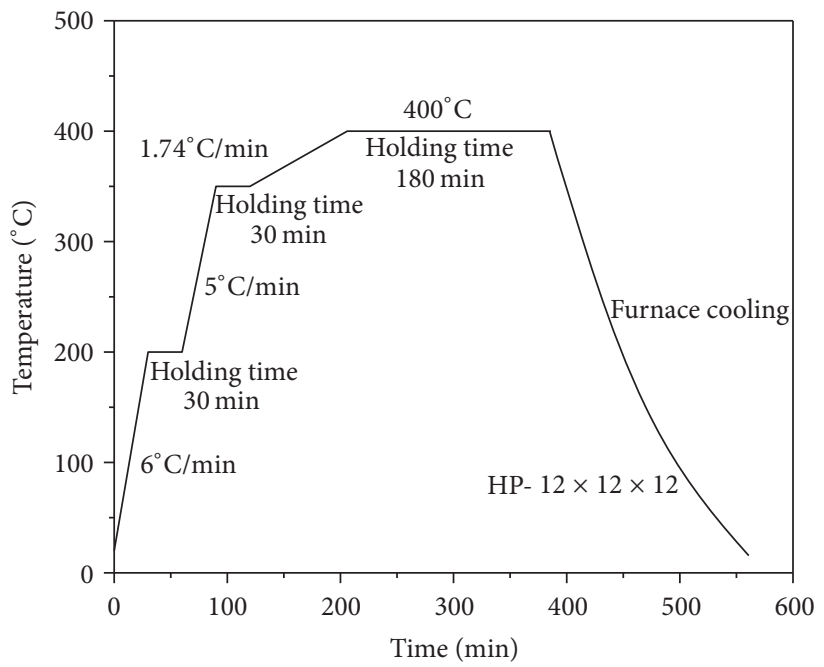

Figure 3: Process flow of the vacuum hot-pressing diffusion welding.

oxidation, aluminum oxide on the surface of $\mathrm{SiCp} / \mathrm{Al}$ was completely removed by rubbing, polishing, and ultrasonic cleaning and then blow-dried.

The diffusion welding for combining the glass and the composites was conducted by using the vacuum hot-pressing furnace $(\mathrm{HP}-12 \times 12 \times 12)$. According to the process flow of diffusion welding process given in Figure 3, the vacuum degree was set at $\sim 5 \times 10^{-4} \mathrm{~Pa}$ and the diffusion temperature was set at $400^{\circ} \mathrm{C}$. The holding time of the diffusion welding process was set at $180 \mathrm{~min}$. The reason is that the material is heated evenly and the elements can fully diffuse. When the diffusion welding was completed, the cross section of the combined material was machined out for the microstructure observation.
2.3. Coefficient of Thermal Expansion of the Glass and Composites. The sealing quality of bismuthate glass and the fabricated composites might be deteriorated by the strain incompatibility at their interfaces. Influenced by the difference of coefficient thermal expansion (CTE) at their interfaces, the strain incompatibility is likely to be produced during the cooling course after completing the sealing process. Hence, the CTE values of the glass and the fabricated composites with different volume fraction are necessary to know. The NETZSCH DIL402PC (with the working temperature from $0 \sim 1400^{\circ} \mathrm{C}$ ) was carried out for the CTE testing. The glass and the fabricated composites were all machined out to cylindrical samples with the dimension of $\Phi 6 \mathrm{~mm} \times 25 \mathrm{~mm}$. Since the diffusion welding process was conducted at $400^{\circ} \mathrm{C}$, 


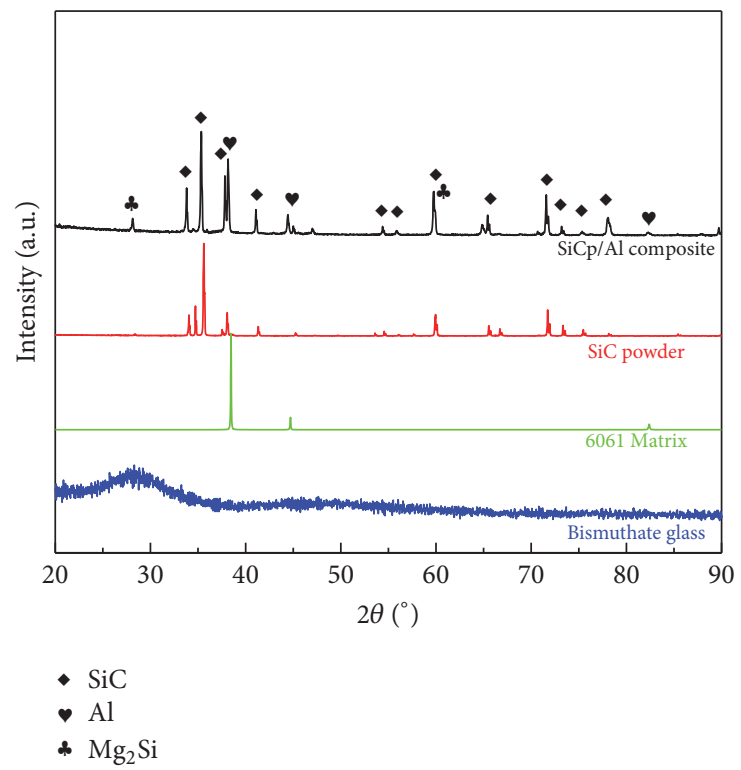

FIGURE 4: XRD patterns of the bismuthate glass, $\mathrm{SiC}$ powders, $6061 \mathrm{Al}$ matrix, and the fabricated $\mathrm{SiC}_{\mathrm{p}} / 6061 \mathrm{Al}$ composites.

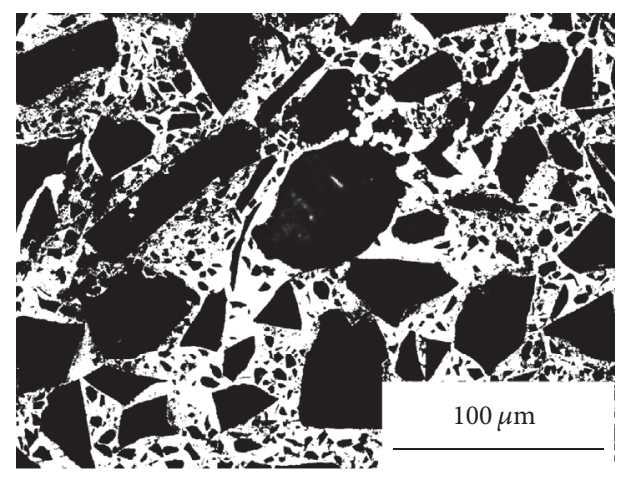

(a)

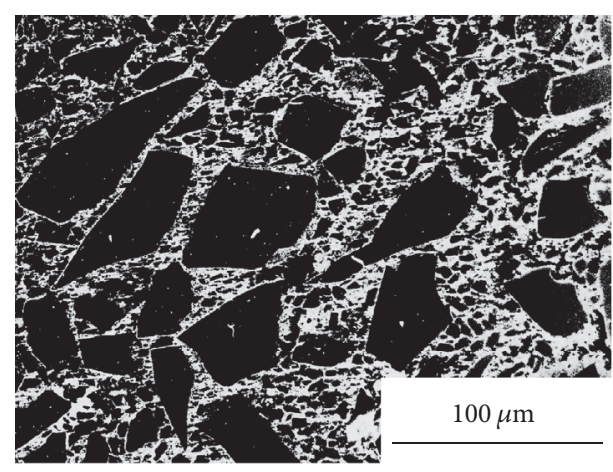

(c)

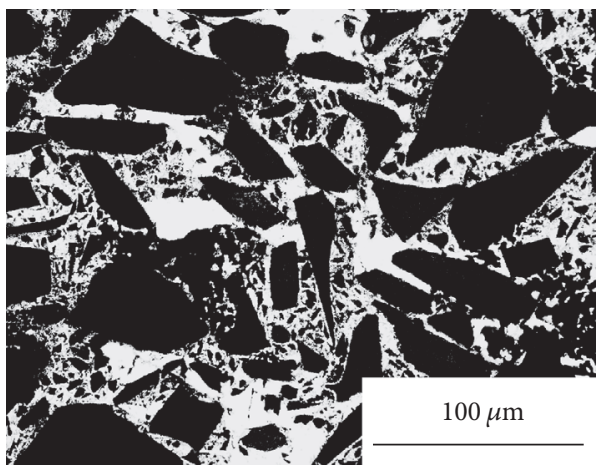

(b)

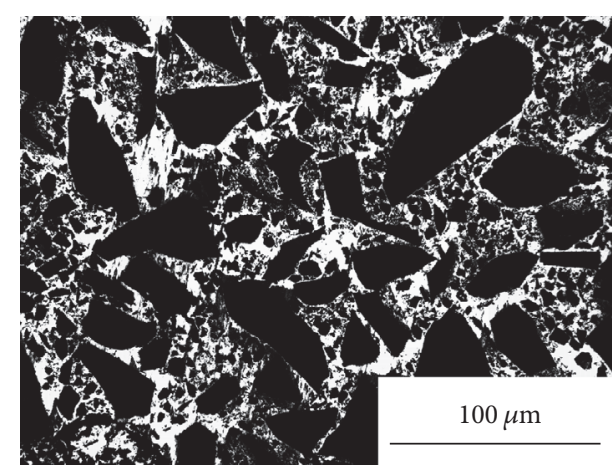

(d)

Figure 5: Optical microstructures of $\mathrm{SiC}_{\mathrm{p}} / \mathrm{Al}$ composites with different additions of SiC particles: (a) 60 vol.\%, (b) 65 vol.\%, (c) 70 vol.\%, and (d) 75 vol.\%.

the testing range of CTE value was set at the range of $25 \sim$ $400^{\circ} \mathrm{C}$.

2.4. Shear Strength Measurement of the Sealing Interface. In order to know the bonding property at the glass/composite interface, shear strength testing (based on the standard of GB/T 12830-91) was conducted by using the Instron 3356 universal testing machine. The cylindrical glass with the dimension of $\Phi 75 \mathrm{~mm} \times 15 \mathrm{~mm}$ was fabricated, and it was sealed by diffusion welding process on the $\mathrm{SiC}_{\mathrm{p}} / \mathrm{Al}$ matrix. 

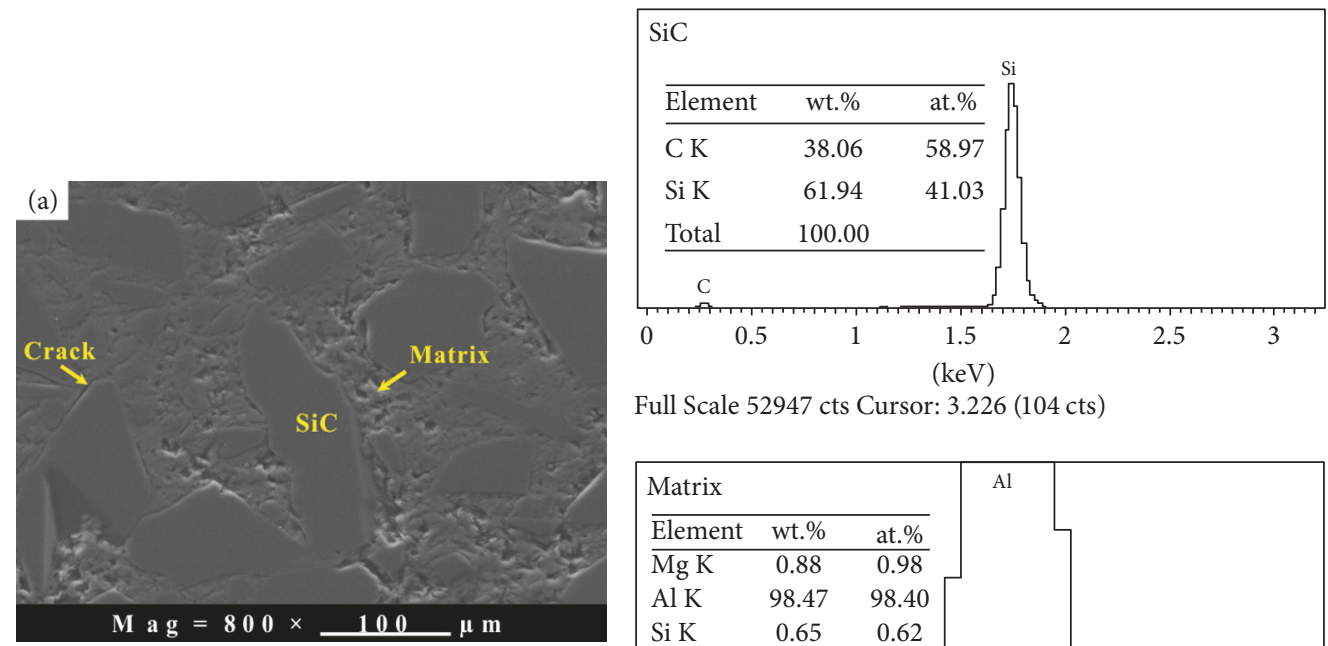

Full Scale 52947 cts Cursor: 3.226 (104 cts)

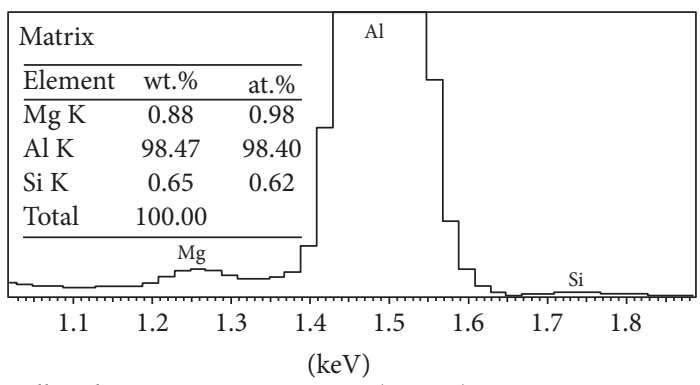

Full Scale 4738 cts Cursor: 1.624 (181 cts)

(a)

(b)

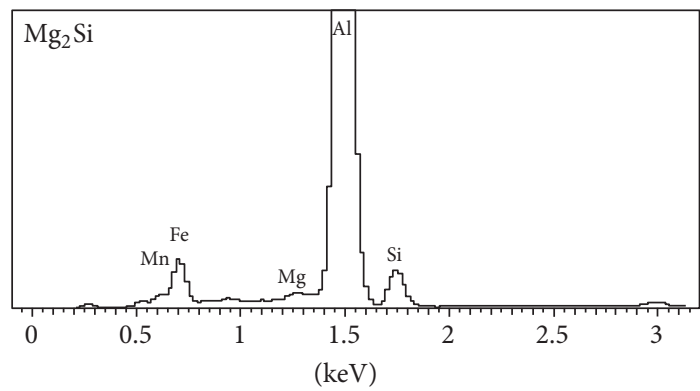

Full Scale 11968 cts Cursor: 3.178 (161 cts)

\begin{tabular}{lcc}
\hline Element & wt.\% & at.\% \\
\hline Mg K & 0.41 & 0.49 \\
Al K & 76.89 & 84.40 \\
Si K & 5.84 & 6.61 \\
Mn K & 1.46 & 0.78 \\
Fe K & 15.41 & 8.17 \\
Total & 100.00 & \\
\hline
\end{tabular}

(b)

FIgURE 6: The morphologies of the $\mathrm{SiC}_{\mathrm{p}} / 6061 \mathrm{Al}$ composite and the 6061 matrix. (a) Morphologies of the phases in the matrix of $\mathrm{SiC}_{\mathrm{p}} / 6061 \mathrm{Al}$ and (b) intermetallic phase in the matrix of $\mathrm{SiC}_{\mathrm{p}} / 6061 \mathrm{Al}$ composite.

The nominal shear strength $\tau$ on the testing samples can be determined via

$$
\tau=\frac{F_{\max }}{S}
$$

where $F_{\max }$ and $S$ are the maximum shear and the effective bearing area of the sealed cylindrical sample, respectively. The effective bearing area $S$ is about $4.41 \times 10^{-3} \mathrm{~m}^{2}$.

\section{Results}

3.1. XRD Analysis and Identification and Microstructure Observation. Figure 4 shows the XRD patterns of the bismuthate glass, the composite matrix, and the fabricated $\mathrm{SiC}_{\mathrm{p}} / 6061 \mathrm{Al}$ composite. Obviously, no sharp peak is revealed in the pattern of bismuthate glass. It indicates that the glass did not undergo crystallization during the melting process and the powdery sample was amorphous. Compared with 


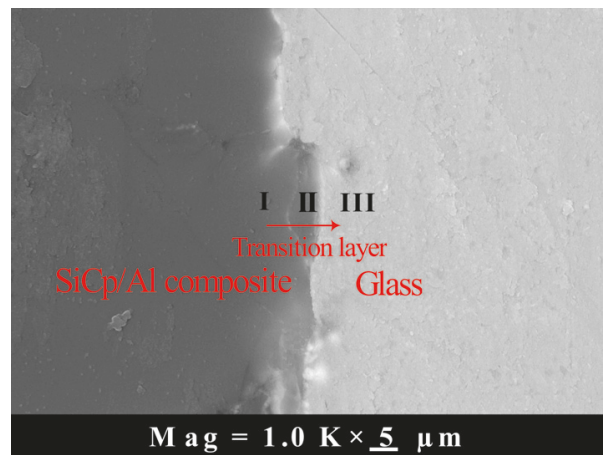

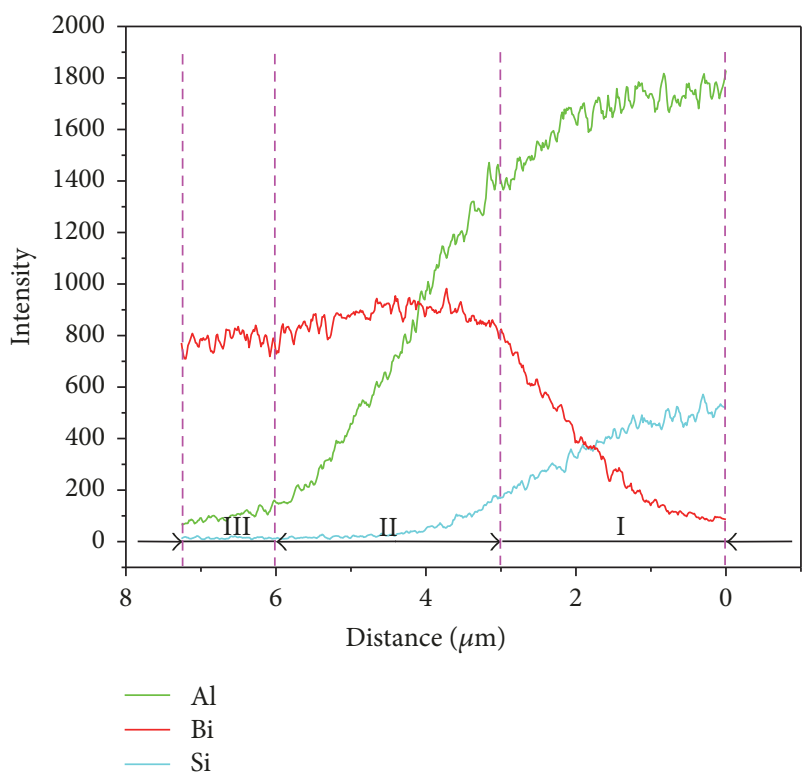

(b)

FIGURE 7: The interface micrograph and $\mathrm{X}$-ray line scans obtained from the high volume fraction $\mathrm{SiC}_{\mathrm{p}} / \mathrm{Al}$ and bismuthate glass.

the $\mathrm{Al}$ matrix, the amount of the elements such $\mathrm{Mg}, \mathrm{Si}$, and $\mathrm{Fe}$ is very low. Hence, the intensity of the $\alpha$-Al peaks is far more stronger than the others in the pattern of the composite matrix. All the peaks revealed in the pattern of the $\mathrm{SiC}$ powders are matched with the standard diffraction card. It also can be found that the peaks corresponding to $\mathrm{Mg}_{2} \mathrm{Si}$ phase are revealed in the $\mathrm{SiC}_{\mathrm{p}} / 6061 \mathrm{Al}$ composite.

3.2. Microstructure of the $\mathrm{SiC}_{\mathrm{p}} / 6061 \mathrm{Al}$ Composites. The optical microstructures of the fabricated $\mathrm{SiC}_{\mathrm{p}} / 6061 \mathrm{Al}$ composites with different volume fraction (namely, $60 \%, 65 \%, 70 \%$, and $75 \%$, respectively) of $\mathrm{SiC}$ particles are given in Figure 5. It is clear that the area fraction of the reinforcements in the microstructure is increased with the increase of $\mathrm{SiC}$ volume fraction. The reinforcements with different sizes are revealed in these microstructures, because the composites have been fabricated by using the $\mathrm{SiC}$ powder with the median diameters at $2 \mu \mathrm{m}, 8 \mu \mathrm{m}$, and $128 \mu \mathrm{m}$. Compared with Figure 5(d), Figures 5(a), 5(b), and 5(c) show the distribution of the reinforcements is relatively uniform. The agglomeration phenomenon on the small particles can be found in Figure 5(d). The morphologies of the $\mathrm{SiC}_{\mathrm{p}} / 6061 \mathrm{Al}$ composite are characterized by SEM/EDS in Figure 6. It is clear that only a few cracks reveal at the boundaries of the large $\mathrm{SiC}$ particles (diameter $>100 \mu \mathrm{m}$ ). But several voids still can be found in the matrix and some places of the boundaries. Obviously, the small particles (diameter $<10 \mu \mathrm{m}$ ) are distributed in the matrix and the boundaries of the large $\mathrm{SiC}$ particles (see details in Figure 5). It can be deduced that the voids resulted from the agglomeration of the particles with low median diameter. The bonding of the agglomerated particles is weaker than the bonding property of $\mathrm{SiC} /$ matrix interface. It might lead to the peeling off of the particles during the polishing process of the $\mathrm{SiC}_{\mathrm{p}} / \mathrm{Al}$ interface [10].
3.3. Sealing Interface of Bismuthate Glass and $\mathrm{SiC}_{\mathrm{p}} / 6061 \mathrm{Al}$ Composites. Figure 7 shows the morphology of the $\mathrm{SiC}_{\mathrm{p}} / \mathrm{Al}$ composite-bismuthate glass material at a magnification $(1000 \mathrm{x})$. The microstructure can be divided into three regions. As seen from the microstructure, Region $\mathrm{I}$ is the $\mathrm{SiC}_{\mathrm{p}} / \mathrm{Al}$ composite which reveals the $\mathrm{SiC}$ reinforcements and the $\mathrm{Al}$ matrix. In this region, the concentration of Si element is high because of the uniformly distributed $\mathrm{SiC}$ particles. Region II is the transition layer, because the concentration of $\mathrm{Bi}$ element gradually changes with the various of the distance. Region III is the bismuthate glass. In this region, the concentration of $\mathrm{Si}$ is decreased, but the concentration of $\mathrm{Bi}$ element is stable. Moreover, it is found that the thickness of the transition layer (Region II) is about $9 \mu \mathrm{m}$. The diffusion distance of these transition layer is obvious in the $\mathrm{SiC}_{\mathrm{p}} / \mathrm{Al}$ composite-glass material interface, suggesting that strong chemical affinity existed between the glass and the composite [11].

3.4. CTE of $\mathrm{SiC}_{\mathrm{p}} / \mathrm{Al}$ Composites and Bismuthate Glass. The CTE values (tested at $25^{\circ} \mathrm{C}$ ) of bismuthate glass and the $\mathrm{SiC}_{\mathrm{p}} / 6061 \mathrm{Al}$ composites with $60 \%, 65 \%, 70 \%$, and $75 \%$ particles are listed in Table 3. It indicates that the CTE value of the in-house fabricated bismuthate glass is close to the composites with different fraction of $\mathrm{SiC}$ particles. However, the difference of CTE values between the bismuthate glass and the composites, represented by the symbol of $\Delta \delta$ in Figure 8, is enlarged with the increase of CTE testing temperature. Compared with the composites with relatively lower $\mathrm{SiC}$ fraction (such as the $60 \% \mathrm{SiC}_{\mathrm{p}} / \mathrm{Al}$ ), the bigger fraction of the $\mathrm{SiC}$ leads to the lower $\Delta \delta$ value. The CTE relationship of the $75 \mathrm{vol} . \% \mathrm{SiC}_{\mathrm{p}} / \mathrm{Al}$ composite with $\mathrm{Al}$ and $\mathrm{SiC}$ is shown in Figure 9. The specific value is in Table 4. 


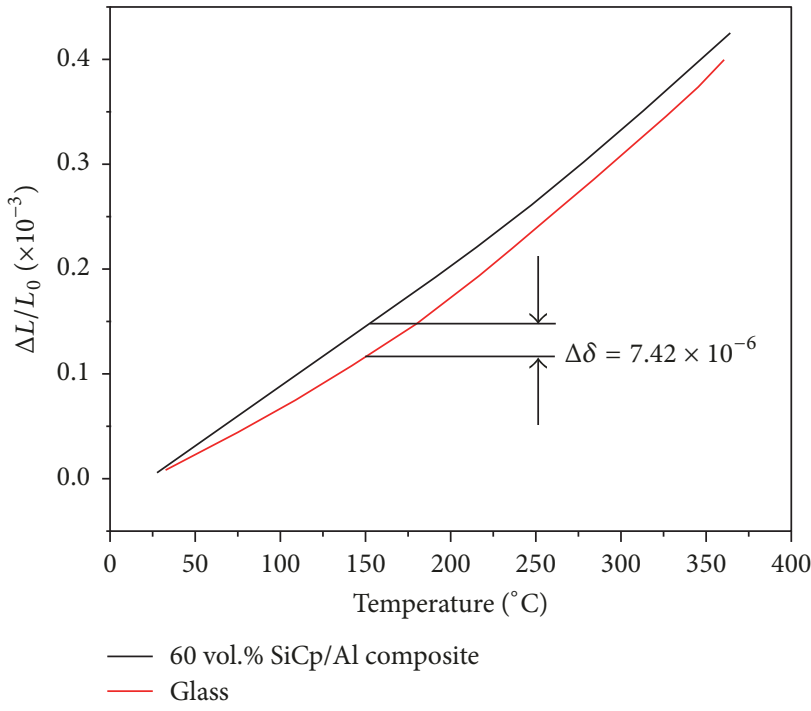

(a)

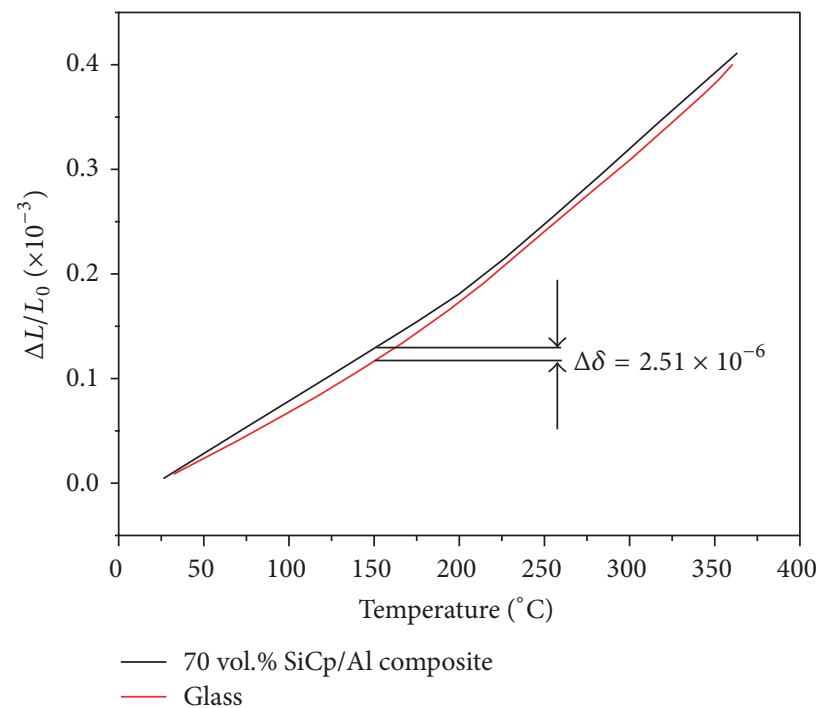

(c)

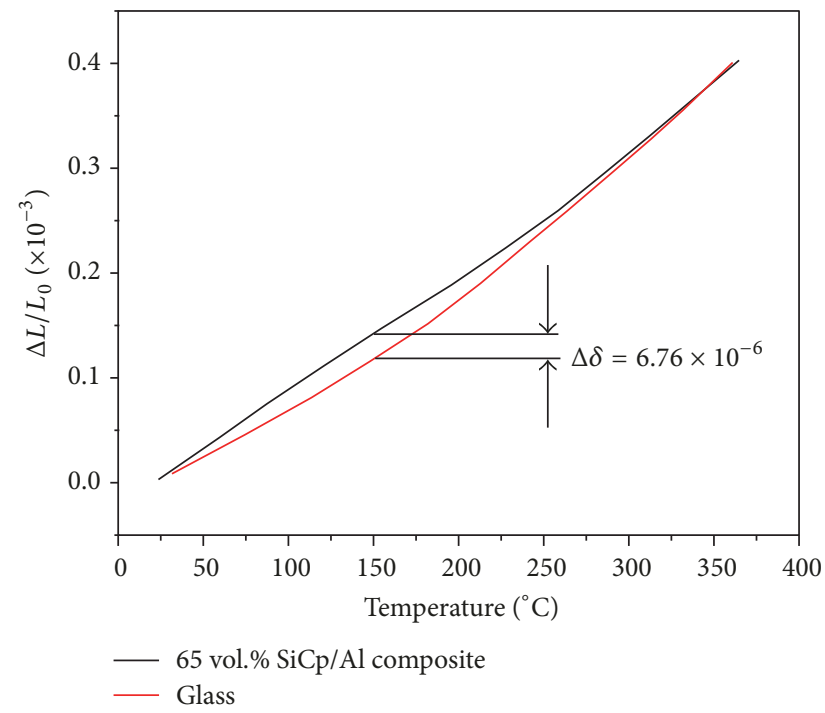

(b)

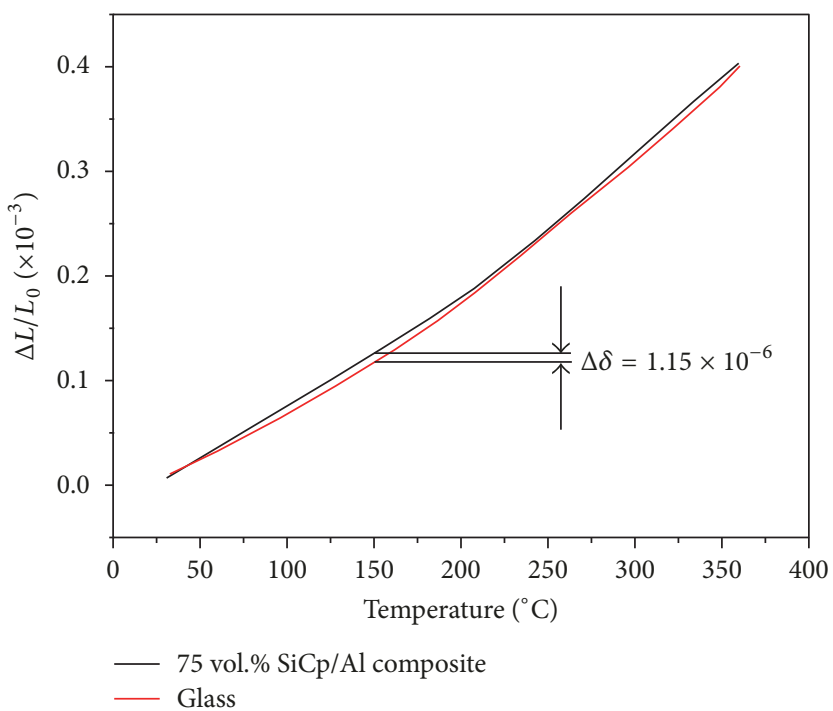

(d)

FIGURE 8: Thermal expansion coefficient comparison between high volume fraction $\mathrm{SiC}_{\mathrm{p}} / \mathrm{Al}(60 \%, 65 \%, 70 \%$, and $75 \%)$ and bismuthate glass.

TABLE 3: CTE values of the bismuthate glass and the $\mathrm{SiC}_{\mathrm{p}} / 6061 \mathrm{Al}$ composites with different vol.\% (tested at $25^{\circ} \mathrm{C}$ ).

\begin{tabular}{|c|c|c|c|c|c|}
\hline Materials & Bismuthate glass & $\begin{array}{c}60 \% \\
\mathrm{SiC}_{\mathrm{p}} / \mathrm{Al} 6061\end{array}$ & $\begin{array}{c}65 \% \\
\mathrm{SiC}_{\mathrm{p}} / \mathrm{Al} 6061\end{array}$ & $\begin{array}{c}70 \% \\
\mathrm{SiC}_{\mathrm{p}} / \mathrm{Al} 6061\end{array}$ & $\begin{array}{c}75 \% \\
\mathrm{SiC}_{\mathrm{p}} / \mathrm{Al} 6061\end{array}$ \\
\hline CTE value & $12.029 \times e^{-06}$ & $13.6180 \times e^{-06}$ & $12.9840 \times e^{-06}$ & $12.1081 \times e^{-06}$ & $12.053 \times e^{-06}$ \\
\hline
\end{tabular}

TABLE 4: CTE values of the $\mathrm{SiC}_{\mathrm{p}} / 6061 \mathrm{Al}$ composite with $\mathrm{Al}$ and $\mathrm{SiC}$ (tested at $25^{\circ} \mathrm{C}$ ).

\begin{tabular}{lccc}
\hline Materials & $\mathrm{SiC}$ & $\mathrm{Al}$ & $75 \% \mathrm{SiC}_{\mathrm{p}} / \mathrm{Al6061}$ \\
\hline CTE value & $4.722 \times e^{-06}$ & $16.126 \times e^{-06}$ & $12.053 \times e^{-06}$ \\
\hline
\end{tabular}

3.5. Shear Strength of Bismuthate/Composite Interface. The schematic diagram of the test sample for shear strength is given as shown in Figure 10. The shear strength of these sealed bismuthate glass- $\mathrm{SiC}_{\mathrm{p}} / \mathrm{Al}$ composites samples $(60 \%$,
$65 \%, 70 \%$, and $75 \%$ ) is concluded in Figure 11, which shows a remarkable increasing trend. The shear strength values of the $60 \%$ and $75 \%$ samples are 4.01 and $4.23 \mathrm{MPa}$, respectively. When the $\mathrm{SiC}$ fraction in the $\mathrm{SiC}_{\mathrm{p}} / \mathrm{Al}$ composites increases to $70 \%$, the shear strength suddenly increases to $5.34 \mathrm{MPa}$, which is $26 \%$ higher than that of the $65 \% \mathrm{SiC}_{\mathrm{p}} / \mathrm{Al}$ sample. The shear strength of the $75 \% \mathrm{SiC}_{\mathrm{p}} / \mathrm{Al}$ sample is $5.53 \mathrm{MPa}$, which is close to the value of the $70 \% \mathrm{SiC}_{\mathrm{p}} / \mathrm{Al}$ sample.

The observation for the fracture surface is helpful to disclose the fracture mechanism of the shear strength 


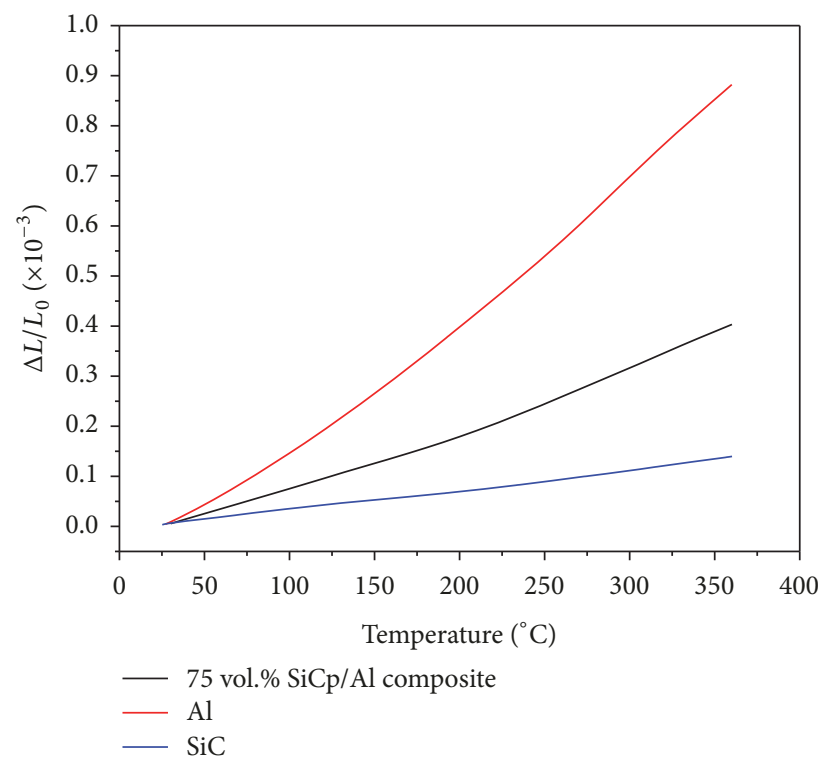

FIgURE 9: The relationship of the 75 vol.\% $\mathrm{SiC}_{\mathrm{p}} / \mathrm{Al}$ composite with $\mathrm{Al}$ and $\mathrm{SiC}$.

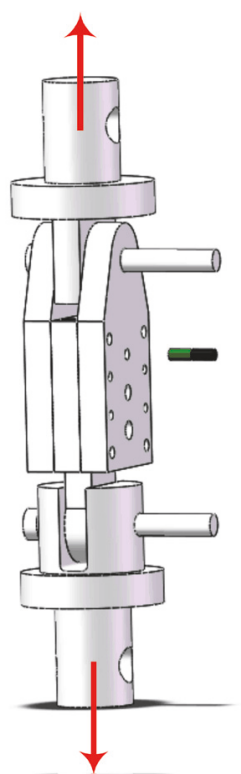

FIGURE 10: The schematic diagram of the test sample for shear strength.

samples. Figure 12(a) shows the fracture surface of the sample fabricated by points out the composite matrix of the interface. Compared with area of the composite matrix in Figure 12(a), the corresponding area in Figure 12(b) is larger. Moreover, this area in Figure 12(c) is larger than that of Figure 12(b). Figure 12(d) is the fracture surface of the sample fabricated by sealing the bismuthate glass and the $75 \% \mathrm{SiC}_{\mathrm{p}} / \mathrm{Al}$ sample. In this fracture pattern, most of the area is the composite matrix. The content of $\mathrm{SiC}$ in the composite is vol. $60 \%$, vol. $\% 65 \%$, vol. $\%$ 70\%, and vol.\% 75\% versus Figures 12(a), 12(b), 12(c), and $12(\mathrm{~d})$, respectively.

\section{Conclusions}

(1) The bismuthate glass and the $\mathrm{SiC}_{\mathrm{p}} / \mathrm{Al}$ composite were successfully sealed after preoxidizing the composite at $500^{\circ} \mathrm{C}$ with the holding time of $600 \mathrm{~min}$ in the air to obtain an $\mathrm{Al}_{2} \mathrm{O}_{3}$ layer.

(2) The line scanning result indicated the $\mathrm{Bi}$ element in bismuthate glass had been diffused into the $\mathrm{SiC}_{\mathrm{p}} / \mathrm{Al}$ composite matrix.

(3) The higher the particle content was, the lower the CTE value was, which led to the high bonding strength of the sealing interface. 


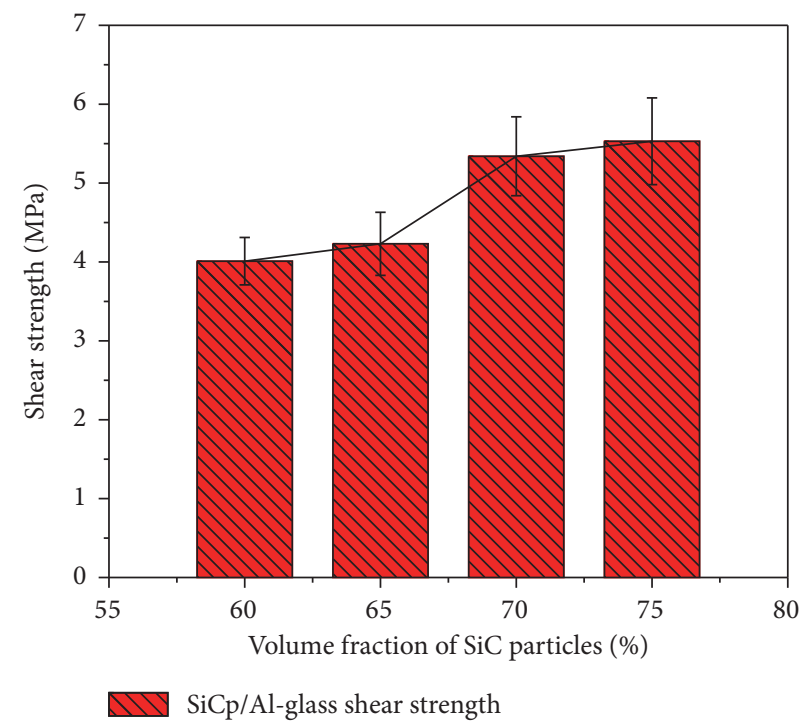

FIGURE 11: Shear strength morphology of the $\mathrm{SiC}_{\mathrm{p}} / \mathrm{Al}$ composite-glass material.

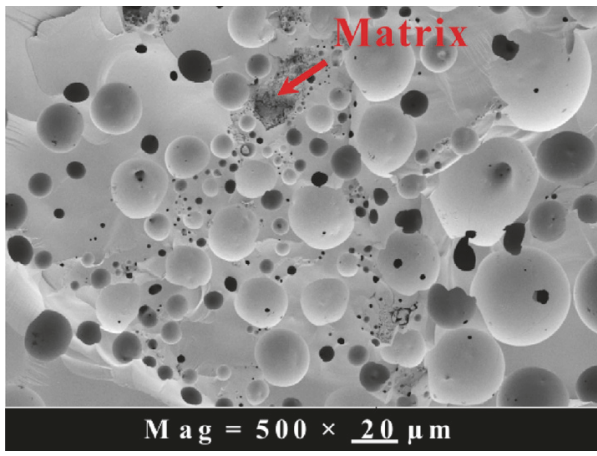

(a)

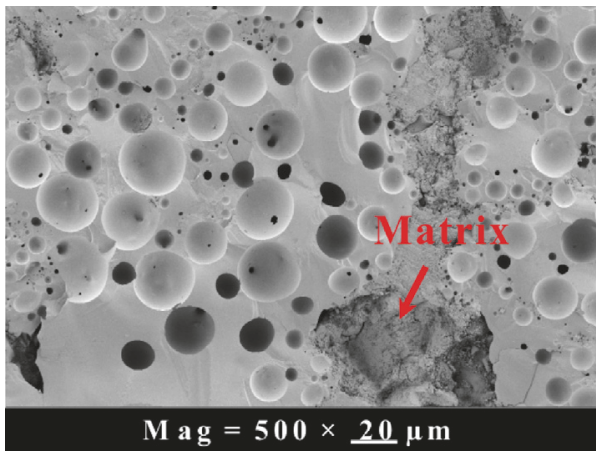

(c)

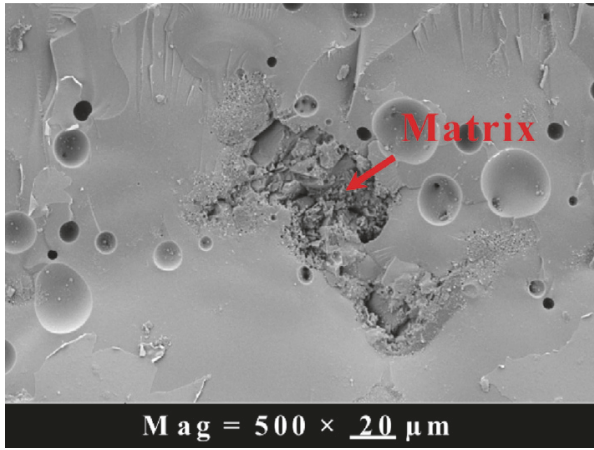

(b)

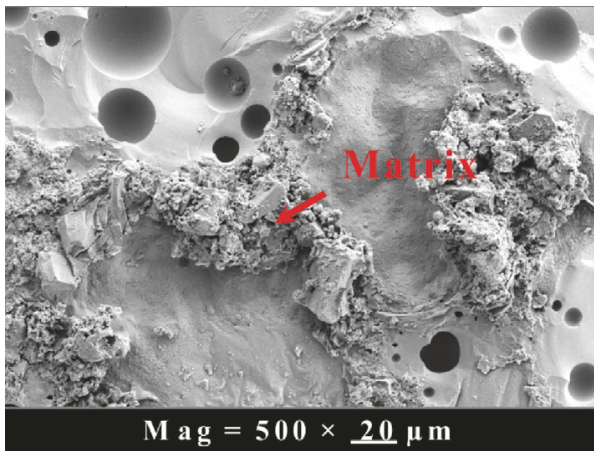

(d)

FIGURE 12: The fracture morphology of the composite-glass material.

\section{Conflicts of Interest}

The authors declare that there are no conflicts of interest regarding the publication of this paper.

\section{Acknowledgments}

This study was funded by the National Major Project of China (JCKY2016208A002). All investigations were performed in the Laboratory of Advanced Materials Processing at South China University of Technology.

\section{References}

[1] Z. Huang, G. Liu, X. Liu, Z. Chen, and D. Jiang, "Manufacture of large-scale lightweight $\mathrm{SiC}$ mirror for space," Image Processing and Optical Engineering vol, 2012. 
[2] S. Liqiang, Y. Shimo, C. Zhiyuan, and Z. Xinyu, "Study on optimization design and application of beryllium-mirror of space astronomical instruments," in Proceedings of the $3 \mathrm{rd}$ International Symposium on Advanced Optical Manufacturing and Testing Technologies, AOMATT 2007: Large Mirrors and Telescopes, July 2007.

[3] S. Behar-Lafenetre, L. Cornillon, and S. Ait-Zaid, "Strength of Zerodur (R) for mirror applications," in Proceedings of SPIE, M. Krodel, JL. Robichaud, and WA. Goodman, Eds., 2015.

[4] T. W. Hobbs, M. Edwards, and R. VanBrocklin, "Current fabrication techniques for $\mathrm{ULE}^{\circledR}$ and fused silica lightweight mirrors," in Proceedings of the Optical Materials and Structures Technologies, W. A. Goodman, Ed., pp. 1-11, August 2003.

[5] O. Vlasenko, A. Zverev, and M. Sachkov, "Using the DP-190 glue for adhesive attachment of a large space mirror and its rim," in Proceedings of the Advances in Optical and Mechanical Technologies for Telescopes and Instrumentation, R. Navarro, C. R. Cunningham, and A. A. Barto, Eds., June 2014.

[6] M. Gao, J. Zhang, J. Li et al., "Feasibility analysis of high volume fraction $\mathrm{SiC} / \mathrm{Al}$ mirror application in space optics," Hongwai yu Jiguang Gongcheng/Infrared and Laser Engineering, vol. 41, no. 7, pp. 1803-1807, 2012.

[7] S. Guo, G. Zhang, L. Li, W. Wang, and X. Zhao, "Effect of materials and modelling on the design of the space-based lightweight mirror," Materials and Corrosion, vol. 30, no. 1, pp. 9-14, 2009.

[8] S. Qu, H. Lou, X. Li, and T. Kuang, "Preparation of $\mathrm{SiC}_{p} / \mathrm{Al}$ composite-bismuthate glass material and its application in mirror blanks," in RSC ADV, vol. 5, pp. 52167-52173, 5, 2015.

[9] C. Chanmuang, M. Naksata, T. Chairuangsri, H. Jain, and C. E. Lyman, "Microscopy and strength of borosilicate glassto-Kovar alloy joints," Materials Science and Engineering: A Structural Materials: Properties, Microstructure and Processing, vol. 474, no. 1-2, pp. 218-224, 2008.

[10] K. Wang, W. Li, J. Du, P. Tang, and J. Chen, "Preparation, thermal analysis and mechanical properties of in-situ $\mathrm{Al} 2 \mathrm{O} 3 / \mathrm{SiO} 2(\mathrm{p}) / \mathrm{Al}$ composites fabricated by using zircon tailing sand," Materials and Corrosion, vol. 99, pp. 303-313, 2016.

[11] I. W. Donald, "Preparation, properties and chemistry of glassand glass-ceramic-to-metal seals and coatings," Journal of Materials Science, vol. 28, no. 11, pp. 2841-2886, 1993. 

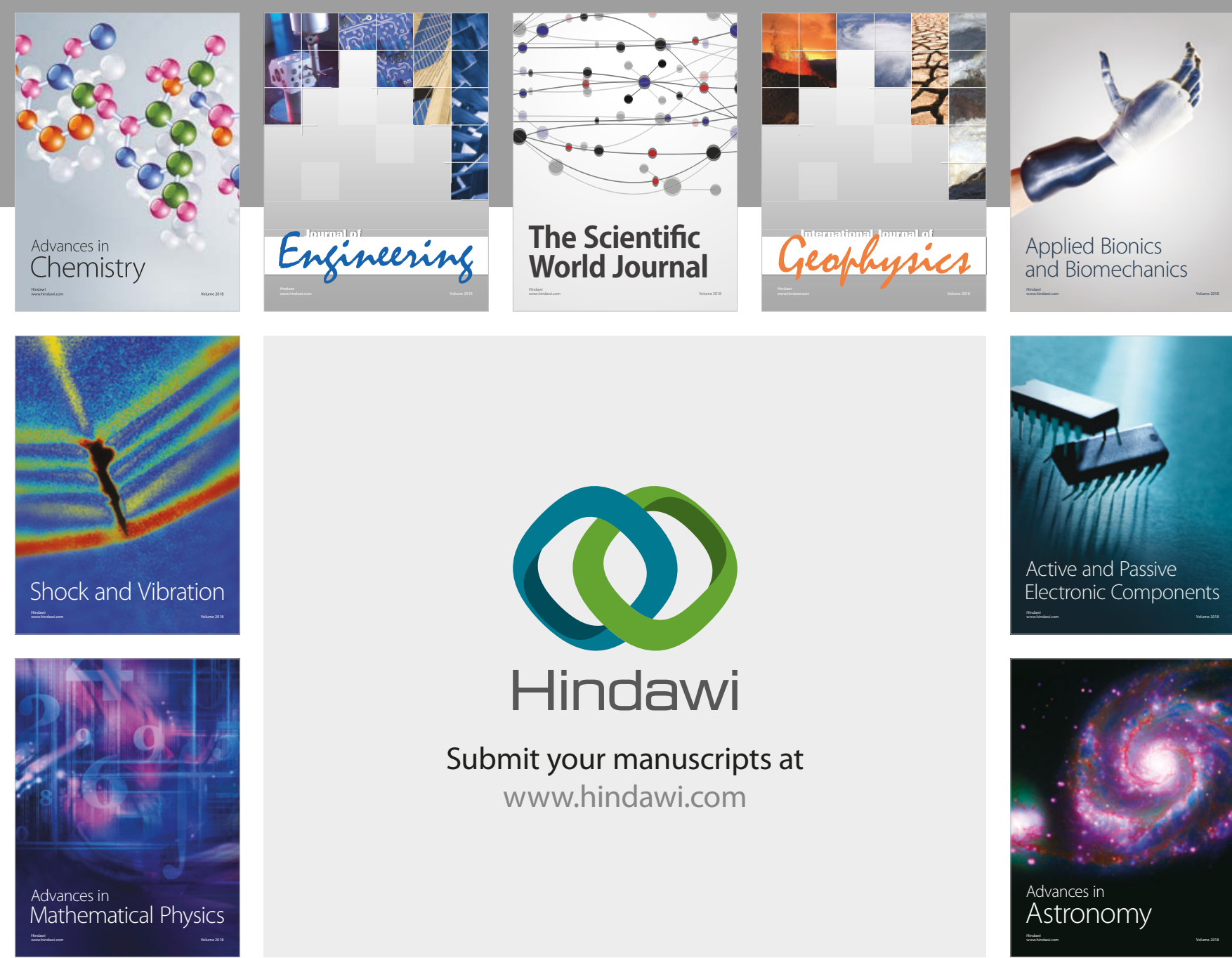

Submit your manuscripts at

www.hindawi.com

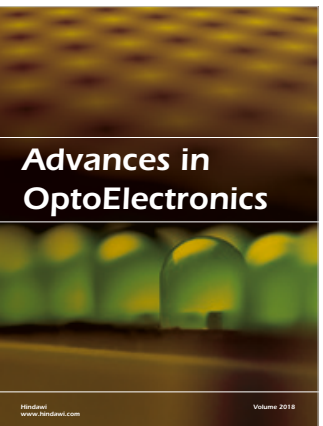

\section{Rotcting Machinery}
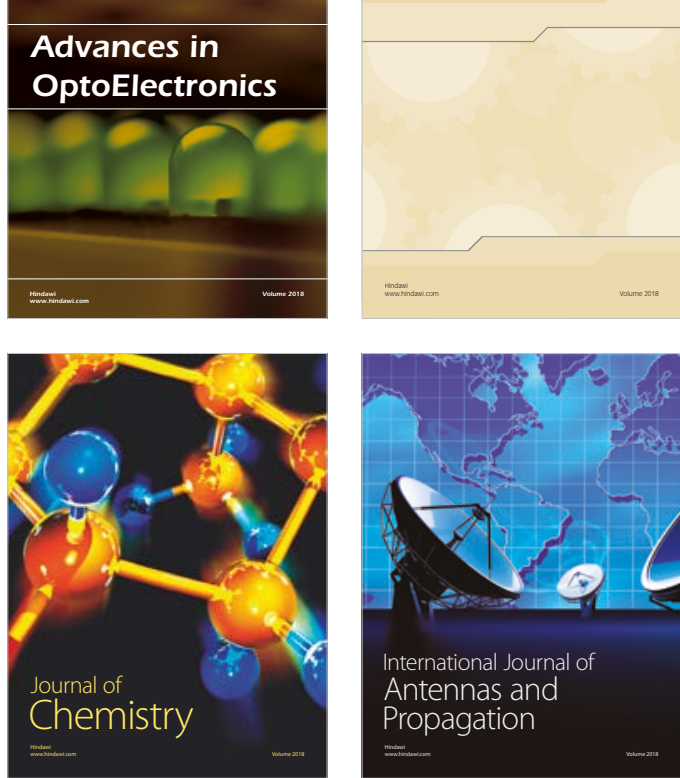

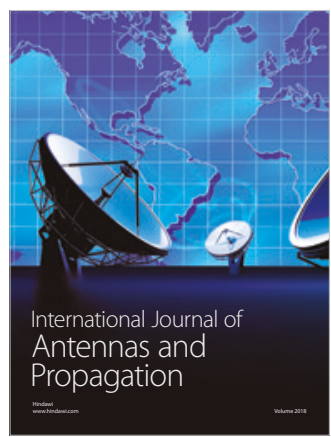

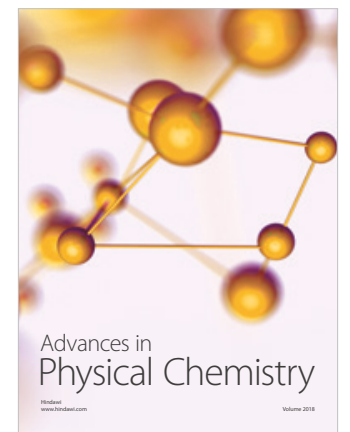

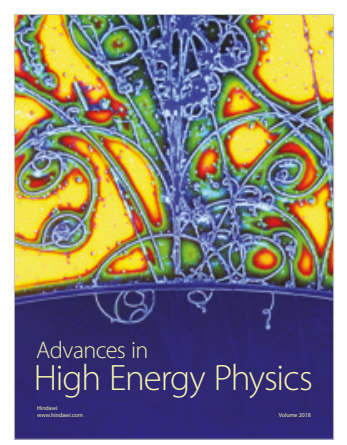

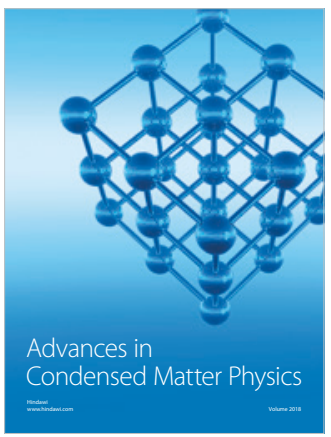

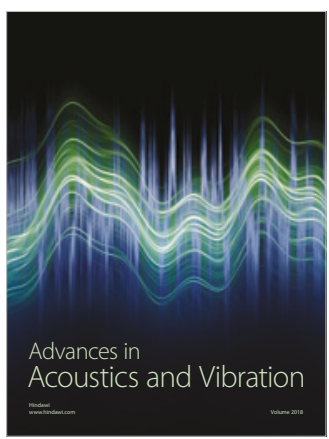

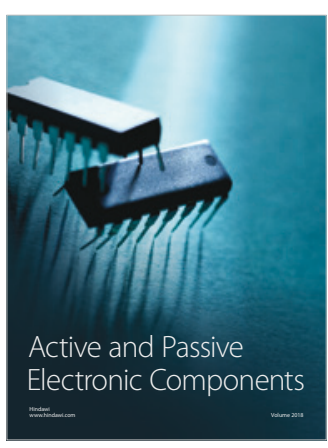
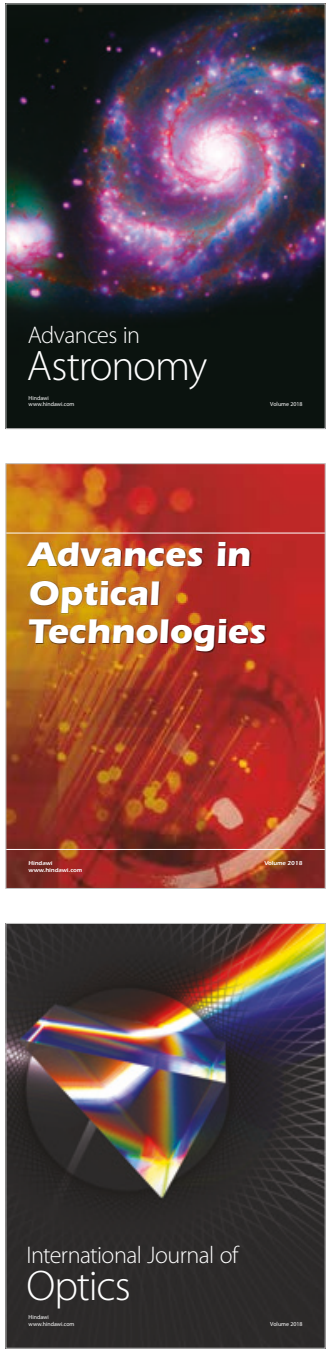